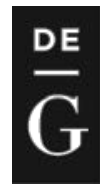

Contemporary Agriculture Vol. 65, No. 1 - 2, Pp. 53 - 59, 2016.

\title{
WATER-YIELD RELATIONS OF DRIP IRRIGATED WATERMELON IN TEMPERATE CLIMATIC CONDITIONS
}

\author{
Borivoj PEJIĆ ${ }^{1}$, Ksenija MAČKIĆ ${ }^{1}$, Srdjan PAVKOVIĆ ${ }^{1}$, Branka LJEVNAIĆ-MA $\check{S} I C^{1}$, \\ Miroljub AKSIĆ ${ }^{2}$ Jelica GVOZDANOVIĆ-VARGA ${ }^{3}$
}

\begin{abstract}
Summary: The objective of the study, conducted in Vojvodina a northern part of the Serbia Republic, was to analyse the effect of drip irrigation on yield, evapotranspiration and water productivity of watermelon (Cirullus lanatus Thunb.) grown with plasticulture. Irrigation was scheduled on the basis of water balance method. Daily evapotranspiration was computed using the reference evapotranspiration and crop coefficient. The yield of watermelon in irrigation conditions (37,28 t/ha) was significantly higher compared to non irrigated (9,98 t/ha). Water used on evapotranspiration in irrigation conditions was $398 \mathrm{~mm}$ and $117 \mathrm{~mm}$ on non irrigated variant. The crop yield response factor of 1,04 for the whole growing season reveals that relative yield decrease was nearly equal to the rate of evapotranspiration deficit. The values of irrigation water use efficiency and evapotranspiration water use efficiency were $9,93 \mathrm{~kg} / \mathrm{m}^{3}$ and $10,29 \mathrm{~kg} / \mathrm{m}^{3}$ respectively. The determined results could be used as a good platform for watermelon growers in the region, in terms of improvement of the optimum utilization of irrigation water.
\end{abstract}

Key words: irrigation, water use efficiency, yield response factor

\section{INTRODUCTION}

According to the literature (FAO 2015) the leading watermelon-producing countries in the world are China, Turkey, Iran and Brazil. Watermelon (Cirullus lanatus Thunb.) is very important horticultural crops in Serbia. It is grown on 17.530 ha with an average yield of 15,1 t/ha with annual yield production of 265.000 tons (Statistical Yearbook of Serbia, 2004). In arid and semiarid areas, irrigation may supply all or most of the crops needs. In most humid production areas, irrigation is used primarily to supplement infrequent or irregular precipitation during short term droughts. Due to unpredicted amount and distribution of precipitation in the growing season, irrigation in Vojvodina, a northern part of the Serbia Republic is mainly supplemental (Pejić et al., 2011). In the region, watermelon is cultivated under irrigation and rainfed conditions. Various studies conducted in a wide range of environments have demonstrated that watermelon yield increases with irrigation (Erdem and Yuksel, 2003; Simsek et al., 2004). Obviously, on the basis of research results from the literature, it is possible to increase the production of watermelon by well-scheduled irrigation program during the whole growing season. Effect of irrigation on watermelon yield has not been studied in the Vojvodina region.

Preliminary step to a more intensive exploitation of the available agroecological conditions or to the development of irrigation schedules for any crop implies a study of crop requirements for water, that is, the evapotranspiration (ET) for any particular crop. To fully utilize the genetic yield potentials of watermelon and achieve high and stable yields, it is necessary to gain knowledge of the crop's capabilities under conditions of dry farming and irrigation. Many factors can affect the amount of ET occurring in any particular vegetable crops. These include plant, soil, cultural practices, environmental factors (Jones et al., 1984; Allen et al., 1998), applied irrigation system (Al-Jamal et al., 2001). Under no limiting irrigated conditions, daily ET rates for individual vegetable crops

\footnotetext{
${ }^{1}$ Borivoj Pejić, PhD, Associated Profesor, Ksenija Mačkić, PhD, Teaching Assistant, Srdjan Pavković, MS, Branka LJevnaićMašić, PhD, Associated Profesor, University of Novi Sad, Faculty of Agriculture, Sq. Dositej Obradović 8, 21000 Novi Sad, Serbia;

${ }^{2}$ Miroljub Aksić, PhD, Associated Profesor, University of Kosovska Mitrovica, Faculty of Agriculture, Jelene Anžujske bb, 43500 Kosovska Mitrovica, Serbia;

${ }^{3}$ Jelica Gvozdanović-Varga, PhD, Senior Research Associate, Institute of Field and Vegetable Crops, Novi Sad, Maksima Gorkog 30, 21000 Novi Sad, Serbia.

*Corresponding author: e-mail: ksenija@polj.uns.ac.rs, Tel.: +381 214853225
} 
are directly related to the meteorological processes affecting evaporative demand and to the existing stage of growth development or percent crop coverage (Blaney and Criddle, 1962). According to the literature, watermelon has high water requirement. For high yields, the seasonal water requirements of watermelon vary from 240-660 mm, depending on the climate and the total length of the growing period (Erdem and Yuksel, 2003; Kirnak and Dogan, 2009; Bastos et al., 2012; Kuscu et al., 2015).

The yield response to water deficit of different crops is of major importance in production planning. The response of yield to water supply is quantified through the yield response factor $\left(\mathrm{k}_{\mathrm{y}}\right)$ which relates relative yield decrease to relative ET deficits (Doorenbos and Kassam, 1979). A larger $\mathrm{k}_{\mathrm{y}}$ value indicates greater yield losses due to water deficit. Water deficit effect on crops yield can be presented in two ways, for individual growth periods or for the total growing season. Kobossi and Kaveh (2010) suggested $\mathrm{k}_{\mathrm{y}}$ values for the total growing period instead for individual growth stages as the decrease in yield due to water stress during specific periods, such as vegetative and ripening periods, is relatively small compared with the yield formation period, which is relatively large.

The importance of analyzing evapotranspiration water use efficiency $\left(E T_{\text {wue }}\right)$ is illustrated by the efforts of numerous researches to direct total water use for evapotranspiration (ET) towards transpiration as the productive part of water for plants (Allen et al., 1998; Howell, 2001). Wang et al. (1996) pointed out that crop yield depends on the rate of water use, and that all factors increasing yield and decreasing water used for ET favorably affect the ET wue $_{\text {. }}$ Defined as the increase in yield per unit of irrigation water applied, irrigation water use efficiency ( $\left.\mathrm{I}_{\text {wue }}\right)$ can be calculated if the amounts of added water and actual yield increase from irrigation are known. $\mathrm{I}_{\text {wue }}$ provides a more realistic assessment of the irrigation effectiveness. $\mathrm{I}_{\text {wue }}$ generally tends to increase with less irrigation only if that water deficit does not occur at any single growth period (Howell, 2001). Care should be taken when comparing WUE values as many researchers have evaluated WUE in different ways (Howell, 2001). Many studies have been done on the determination of watermelon $\mathrm{ET}_{\text {wue }}$ and $\mathrm{I}_{\text {wue }}$ for different irrigation methods and environmental conditions (Tingwu et al., 2003; Erdem et al., 2005; Kuscu et al., 2015).

Most crops, including watermelon, respond positively to irrigation with respect to growth and yield. Since there are no data on the production of watermelon under irrigation in the region the aim of research was to examine the effect of irrigation on the yield and quality of watermelon. Also, the study was planned to determine the yield response factor in order to response the sensitivity of watermelon to water stress and in such way to obtain additional information that can be useful in the improvement of watermelon growing practices under climate conditions of the Vojvodina region. The established values of water use coefficients $\left(\mathrm{ET}_{\text {wue }}\right.$ and $\mathrm{I}_{\text {wue }}$ ) will be used in analyses of the applied irrigation regime with aim to use water more efficiently in irrigation practice. Estimated values of water use on watermelon evapotranspiration will be compared with those obtained from past studies in similar regions and climatic conditions.

\section{MATERIAL AND METHODS}

Field experiment was carried out at private experimental farm in the Vojvodina province (452 $20^{\prime} \mathrm{N}$ latitude, $19^{\circ} 51^{\prime}$ E longitude and 84 m.a.s.l) on the calcareous chernozem soil of the loess terrace in 2015 . Over the 1964 to 2014 period, the annual mean air temperature, precipitation and relative humidity were $11,2{ }^{\circ} \mathrm{C}, 598,7 \mathrm{~mm}$ and $76 \%$ respectively. According to the Hergreaves climate classification system, the study area is classified as arid in the summer period, from Jun to August (Bošnjak, 2001). In the growing season (April-August), the mean temperature and total rainfall were $19,3{ }^{\circ} \mathrm{C}$ and $114 \mathrm{~mm}$ respectively. As expected, rainfall is not sufficient for watermelon production. For this reason, irrigation is needed for acceptable yields of watermelon grown in the region. The amount of water added by irrigation was $275 \mathrm{~mm}$ (Figure 1, Table 1). 


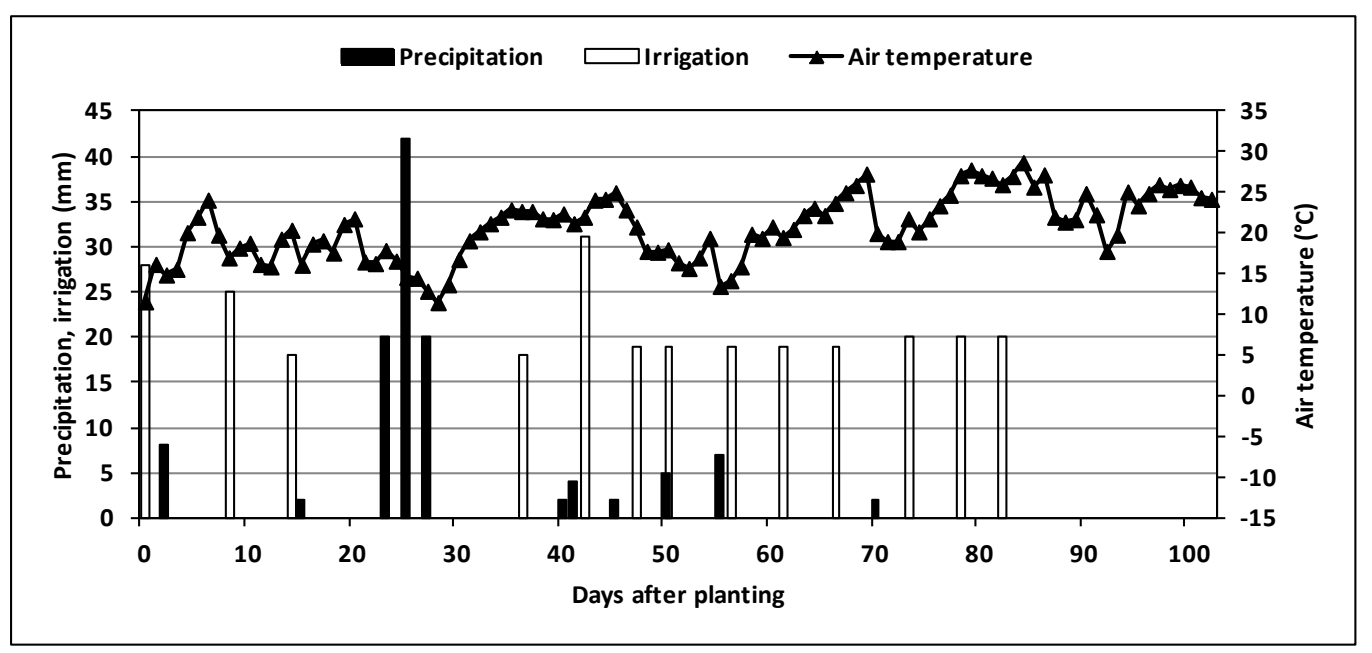

Figure. 1. Irrigation rate and climatic data of the region for the experimental year

Watermelon cultivar Lusia was used for the trials. The trial was established in a system of random blocks in three replicates and adapted to technical specifications of drip irrigation system. The trial included, as well, the nonirrigated, control variant. The previous crop was corn. To prepare the soil for watermelon cultivation, the experimental site was ploughed at the depth of $30 \mathrm{~cm}$ in the autumn. In the month of April, soil surface was prepared for transplantation by disc method. Black polyethylene mulch bed and laterals for irrigation were placed before seedlings were transplanted. Watermelon seedlings were transplanted at the stage of 4-5 leafs on 30 April. A single plot size was $10,8 \mathrm{~m}^{2}(7,2 \mathrm{~m} \times 1,5 \mathrm{~m})$. The crop spacing was 1,2 by $1,5 \mathrm{~m}$. The plants were protected of low temperatures with low plastic tunnels $(1 \mathrm{~m} \mathrm{x} 0,4 \mathrm{~m})$ and drip irrigated with a lateral row per plant row and drippers spaced every $0,2 \mathrm{~m}$. The drippers had an average flow of $1 \mathrm{1} / \mathrm{h}$ under a pressure of $70 \mathrm{kPa}$. All recommended agronomic practices were applied for cultivation and plant protection at the experimental site. A total of $170 \mathrm{~kg} \mathrm{~N} / \mathrm{ha}$, $64 \mathrm{~kg} \mathrm{P}_{2} \mathrm{O}_{5} /$ ha and $96 \mathrm{~kg} \mathrm{~K} 2 \mathrm{O} / \mathrm{ha}$ fertilizer was applied according to recommendations based on the results of the soil analysis. The crop was harvested by hand from 23 July to 10 August. Marketable yield (t/ha) was measured considering fruits free of disorders and available for local markets. Total soluble solids content was measured with a hand-held refractometer (Atago refractometer PAL-1).

Table 1. Irrigation water applied in each crop development stage

\begin{tabular}{cccccc}
\hline \multirow{2}{*}{$\begin{array}{c}\text { Crop development } \\
\text { stage }\end{array}$} & Date & The length of the period (days) & $\begin{array}{c}\text { Rainfall } \\
\text { (mm) }\end{array}$ & $\begin{array}{c}\text { Irrigation water } \\
\text { applied (mm) }\end{array}$ & $\begin{array}{c}\text { No. of } \\
\text { irrigation }\end{array}$ \\
\cline { 2 - 3 } & $30.04-30.05$. & 31 & 92 & 71 & 3 \\
Initial & 17 & 8 & 68 & 3 \\
Crop development & $31.05-16.06$. & 36 & 14 & 136 & 7 \\
Mead season & $17.06-22.07$. & 19 & 0 & 0 & 0 \\
Late season & $23.07-10.08$. & 103 & 114 & 275 & 13 \\
\hline Growing season & $30.04-10.08$ & & &
\end{tabular}

Irrigation was scheduled on the basis of water balance method using reference evapotranspiration $\left(\mathrm{ET}_{\mathrm{o}}\right)$ and crop coefficients (kc). $\mathrm{ET}_{\mathrm{o}}$ was calculated by Hergreaves equation (Hergreaves and Samani, 1985). Daily water used on plants evapotranspiration was calculated by multiplying $\mathrm{ET}_{0}$ with $\mathrm{kc}$ values (according to FAO, 2015) for initial stage 0,5, crop development stage 0,7, mead season stage 1,0 and late season stage 0,65. Irrigation started when readily available water in the soil layer of $30 \mathrm{~cm}$ was completely absorbed by plants.

Yield response factor: The yield response factor $\left(\mathrm{k}_{\mathrm{y}}\right)$ for total growing season was determined using the Steward's model (Doorenbos and Kassam, 1979) as follows: 


$$
\left(1-\frac{\mathrm{Y}_{\mathrm{a}}}{\mathrm{Y}_{\mathrm{m}}}\right)=\mathrm{k}_{\mathrm{y}}\left(1-\frac{\mathrm{ET}_{\mathrm{a}}}{\mathrm{ET}_{\mathrm{m}}}\right)
$$

Where:

$\mathrm{Y}_{\mathrm{a}}=$ the actual harvested yield (non-irrigated, $\mathrm{kg} / \mathrm{ha}$ ), $\mathrm{Y}_{\mathrm{m}}=$ the maximum harvested yield (under irrigation, non limiting conditions, $\mathrm{kg} / \mathrm{ha}$ ), $\mathrm{k}_{\mathrm{y}}$ = the yield response factor, $\mathrm{ET}_{\mathrm{a}}=$ the actual evapotranspiration (mm) corresponding to $\mathrm{Y}_{\mathrm{a}}, \mathrm{ET}_{\mathrm{m}}=$ the maximum evapotranspiration $(\mathrm{mm})$ corresponding to $\mathrm{Y}_{\mathrm{m}},\left(1-\mathrm{ET}_{\mathrm{a}} / \mathrm{ET}_{\mathrm{m}}\right)=$ the relative evapotranspiration deficit, and $\left(1-\mathrm{Y}_{\mathrm{a}} / \mathrm{Y}_{\mathrm{m}}\right)=$ the relative yield decrease.

Water productivity: Irrigation water use efficiency $\left(\mathrm{I}_{\text {wue }}, \mathrm{kg} / \mathrm{m}^{3}\right)$ and evapotranspiration water use efficiency $\left(\mathrm{ET}_{\text {wue }}, \mathrm{kg} / \mathrm{m}^{3}\right)$ were estimated as Bos $(1980,1985)$.

$$
\begin{gathered}
I_{\text {wue }}=\frac{Y_{m}-Y_{a}}{I} \\
E_{\text {wue }}=\frac{Y_{m}-Y_{a}}{E T_{m}-E T_{a}}
\end{gathered}
$$

Where:

$\mathrm{I}=$ the amount of irrigation water applied (mm)

Data reported for yield, yield components and morphological characteristics of watermelon were assessed by analyses of variance (ANOVA) and Fisher's LSD test was used to identify significant differences at the $\mathrm{p}<0,05$ levels between the mean values.

\section{RESULTS}

Yield and fruit characteristics. Irrigation has significantly increased the marketable yield of watermelon. The yield in irrigation conditions (37,28 t/ha) was 3,7 times higher (9,98 t/ha) as compared with control without irrigation (Table 4). Yield components, namely fruit weight, fruit size and height as well as total soluble solids of watermelon were also significantly influenced by irrigation (Table 2) considering the fact that during the mead season there was insufficient amount of rainfall on control variant, only $14 \mathrm{~mm}$ (Figure 1) which caused reduction in examined parameters. The content of total soluble solids of watermelon (Table 2) on irrigated variant (12,03\%) was significantly higher compared to non-irrigated conditions (9,83\%).

Seasonal evapotranspiration, yield response factor and water use efficiency. In the study period, evapotranspiration rate in irrigation conditions $\left(\mathrm{ET}_{\mathrm{m}}\right)$ and in rainfed control variant $\left(\mathrm{ET}_{\mathrm{a}}\right)$ was $398 \mathrm{~mm}$ and $117 \mathrm{~mm}$ respectively (Table 3 and 4 ). The highest evapotranspiration rate $\left(\mathrm{ET}_{\mathrm{m}}\right)$ was measured in the mead season, and amounted $194 \mathrm{~mm}$. In average, the highest value of daily water used on evapotranspiration of watermelon in irrigation conditions $\left(\mathrm{ET}_{\mathrm{m}}\right.$ ) was detected in mead season stage of 5,4 mm, but average value for the entire growing season was 3,7 mm (Table 3). Maximum daily evapotranspiration value of 7,0 mm was detected 70 days after planting by the middle of mead season (Figure 2).

Table 2. Yield components and fruit characteristics of watermelon

\begin{tabular}{cccccc}
\hline Variant & Replicates & Fruit weight $(\mathrm{kg})$ & Fruit size $(\mathrm{cm})$ & Fruit height $(\mathrm{cm})$ & Total soluble solids (\%) \\
\hline \multirow{5}{*}{ Irrigated } & 1 & 4,52 & 20,92 & 19,98 & 12,35 \\
\cline { 2 - 6 } & 2 & 4,83 & 20,95 & 20,93 & 11,78 \\
\cline { 2 - 6 } & 3 & 5,79 & 22,58 & 21,82 & 11,95 \\
\cline { 2 - 6 } & Average & $5,05^{\mathrm{a}}$ & $21,48^{\mathrm{a}}$ & $20,91^{\mathrm{a}}$ & $12,03^{\mathrm{a}}$ \\
\cline { 2 - 6 } Non-irrigated & 1 & 2,44 & 17,00 & 16,10 & 10,85 \\
\cline { 2 - 6 } & 2 & 1,45 & 14,60 & 12,75 & 9,15 \\
\cline { 2 - 6 } & 3 & 1,42 & 13,85 & 13,75 & 9,50 \\
\cline { 2 - 6 } & Average & $1,77^{\mathrm{b}}$ & $15,15^{\mathrm{b}}$ & $14,20^{\mathrm{b}}$ & $9,83^{\mathrm{b}}$ \\
\hline
\end{tabular}

Different letters between the values in the same column denote significant differences (Fisher's LSD test, $\mathrm{p}<0,05$ ) 
Table 3. Watermelon evapotranspiration in each crop development stage

\begin{tabular}{cccccc}
\hline Crop development stage & $\mathrm{ET}_{\mathrm{o}}(\mathrm{mm})$ & $\mathrm{ET}_{\mathrm{m}}(\mathrm{mm})$ & $\mathrm{ET}_{\mathrm{a}}(\mathrm{mm})$ & Water used on $\mathrm{ET}_{\mathrm{m}}(\%)$ & Average daily $\mathrm{ET}_{\mathrm{m}}(\mathrm{mm})$ \\
\hline Initial & 129 & 65 & 65 & 16,3 & 2,1 \\
Crop development & 95 & 67 & 38 & 16,8 & 3,9 \\
Mead season & 194 & 194 & 14 & 48,7 & 5,4 \\
Late season & 103 & 72 & 0 & 18,2 & 3,5 \\
\hline Growing season & 521 & 398 & 117 & 100 & 3,7 \\
\hline
\end{tabular}

$\mathrm{ET}_{\mathrm{o}}$ - reference evapotranspiration; $\mathrm{ET}_{\mathrm{m}}$ - maximum evapotranspiration; $\mathrm{Et}_{\mathrm{a}}$ - actual evapotranspiration

The yield response factor $\left(k_{y}\right)$ was 1,04 for the total crop growing period (Table 4). The value of $k_{y}$ in this study reveals that the relative yield decrease was nearly equal to the rate of ET deficit.

$\mathrm{ET}_{\text {wue }}$ and $\mathrm{I}_{\text {wue }}$ are key indicators that reveal the optimal use of water for plant production. $\mathrm{I}_{\text {wue }}$ and $\mathrm{ET}_{\text {wue }} \mathrm{Were}$ $9,93 \mathrm{~kg} / \mathrm{m}^{3}$ and $10,29 \mathrm{~kg} / \mathrm{m}^{3}$ respectively (Table 4 ).

Table 4. Yield response factor and water productivity of watermelon

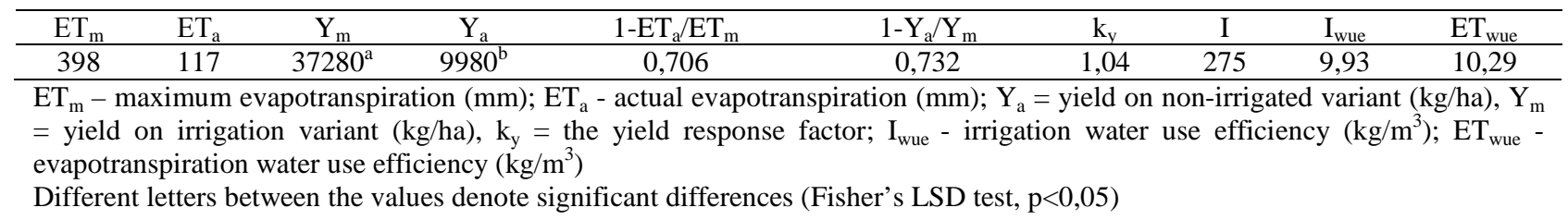

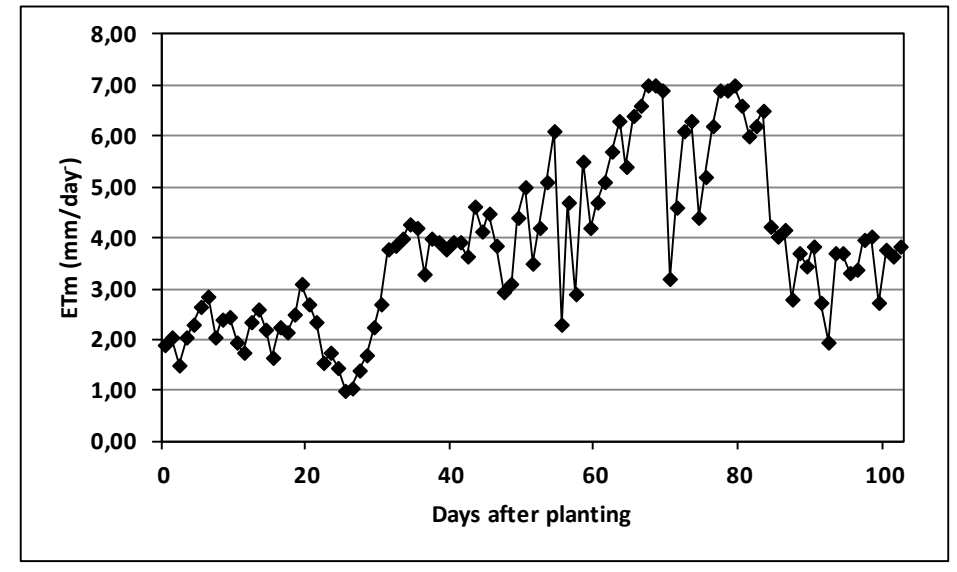

Figure. 2. Daily evapotranspiration in irrigation conditions (ETm)

\section{DISCUSSION}

In irrigation conditions the marketable yield of watermelon has significantly increased as compared with control without irrigation. Considering the fact that during the crop development stage and especially mead season there was insufficient amount of rainfall, irrigation in these conditions is a necessity. Results are in agreement with many studies conducted in a wide range of environments which confirm that irrigation can significantly affect the yield increase of watermelon (Erdem et al., 2001; Tingwu et al., 2003; Kirnak and Dogan, 2009).

Obtained results show that irrigation enables a substantial increase in yield components, namely fruit weight, fruit size and height as well total soluble solids of watermelon. The results of total soluble solids of watermelon were similar with the results of Erdem et al. (2001) for semi-arid conditions of Turkey, who stated that the values of the total soluble solids amounted about $10,7 \%$ in irrigated conditions.

Evapotranspiration rate in irrigation conditions $\left(\mathrm{ET}_{\mathrm{m}}\right)$ was also higher compared to rainfed control variant (ETa), and within the expected values for temperate climatic conditions. Erdem et al. (2001), Erdem and Yuksel (2003), Erdem et al. (2005) detected seasonal ET of watermelon in irrigated conditions in the interval of 363-412 mm and in interval of 163-220 mm in conditions without irrigation in semi-arid conditions of Turkey. To get high and stable yields of watermelon on the level of 80-100 t/ha in semi-arid conditions of Turkey frequent irrigations without any 
deficit of water are needed. Yield reduction from 35-54\% was recorded compared irrigated to non-irrigated, control variant (Erdem and Yuksel, 2003).

The calculated highest value of daily water used on evapotranspiration of watermelon in irrigation conditions $\left(\mathrm{ET}_{\mathrm{m}}\right)$ is in accordance with values obtained by Tingwu et al. (2003), who pointed out that the average daily water use reached the peak of 5-6 mm at watermelon enlargement stage in the climate conditions of China. Maximum daily evapotranspiration value gained from our research is in accordance to environmental requirements and growth stage of watermelon. The same value of maximum daily water used on watermelon evapotranspiration $(7 \mathrm{~mm})$ was recorded by Miranda et al. (2004) in Brazil during the intermediate stage of growing season.

The yield response factor $\left(\mathrm{k}_{\mathrm{y}}\right)$ for the total crop growing period $(1,04)$ reveals that the relative yield decrease was nearly equal to the rate of ET deficit. The result agreed with findings of Senyigit (1998), Kirnak and Dogan (2009) and Kuscu et al. (2015) who found that ky values for the total growing season were 1,07, 1,0 and 1,01 respectively. Erdem and Yuksel (2003) reported a $\mathrm{k}_{\mathrm{y}}$ of 1,27 and emphasized that the watermelon is quite sensitive to soil water deficit during the whole growing period. When watermelon is grown in the area of limited water recourses and maximum production per unit volume of water is being aimed watermelon must have priority in supply of the water compared to other plants. Doorenbos and Kassam (1979), Simsek et al. (2004), Kirnak and Dogan (2009) pointed out $\mathrm{k}_{\mathrm{y}}$ of 1,1, 1,15 and 1,14 respectively and stressed that differences in determined $\mathrm{k}_{\mathrm{y}}$ values could be due management practices (main crop vs. second crop, cultivar type, fertilization) and changes in meteorological conditions.

The values of $\mathrm{ET}_{\text {wue }}$ and $\mathrm{I}_{\text {wue }}$ are obtained from this study are close to those found in other studies. Erdem et al. (2005) reported the $\mathrm{I}_{\text {wue }}$ and $\mathrm{ET}_{\text {wue }}$ of $11,9 \mathrm{~kg} / \mathrm{m}^{3} \mathrm{~mm}$ and $16,6 \mathrm{~kg} / \mathrm{m}^{3} \mathrm{~mm}$ respectively for watermelon grown in semi-arid climate of Turkey.

\section{CONCLUSION}

Based on obtained results it can be concluded that irrigation significantly influenced yield and fruit characteristics of watermelon in temperate climatic conditions of the Vojvodina region. The yield in irrigation conditions $(37,28 \mathrm{t} / \mathrm{ha})$ was 3,7 times higher $(9,98 \mathrm{t} / \mathrm{ha})$ as compared with control without irrigation. Evapotranspiration rate in irrigation conditions $\left(\mathrm{ET}_{\mathrm{m}}\right)$ and in rainfed control variant $\left(\mathrm{ET}_{\mathrm{a}}\right)$ were $398 \mathrm{~mm}$ and $117 \mathrm{~mm}$ respectively. In average, the highest value of daily water used on evapotranspiration of watermelon in irrigation conditions $\left(\mathrm{ET}_{\mathrm{m}}\right)$ was detected in mead season stage of $5,4 \mathrm{~mm} /$ day, but average value for the entire growing season was $3,7 \mathrm{~mm} /$ day. The value of $\mathrm{k}_{\mathrm{y}}$ in this study of 1,04 reveals that the relative yield decrease was nearly equal to the rate of ET deficit. $\mathrm{I}_{\text {wue }}$ and $\mathrm{ET}_{\text {wue }}$ were $9,93 \mathrm{~kg} / \mathrm{m}^{3}$ and $10,29 \mathrm{~kg} / \mathrm{m}^{3}$ respectively. Although one-year studies are not sufficient to obtain final conclusions, the determined results could be used as a good platform for watermelon growers in the region, in terms of improvement of the cropping technology, optimum utilization of irrigation water and for the planning, design and operation of irrigation projects.

\section{ACKNOWLEDGMENT}

This research is a part of project supporting by the Ministry of Education and Science of the Republic of Serbia, Project TR 31030.

\section{REFERENCES}

ALLEN R.G., PEREIRA L.S., RAES D., SMITH M.: Crop evapotranspiration: Guidelines for computing crop water requirements. Irrigation and Drainage Paper 56, FAO, Rome, Italy, 1998.

AL-JAMAL M.S., BALL S., SAMMIS T.W.: Comparison of sprinkler, trickle and furrow irrigation efficiencies for onion production. Agricultural Water Management, 46:253-266, 2001.

BASTOS E.A., SILVA C.R., RODRIGUES B.H.N., ANDRADE J.R., IBIAPINA L.M.M.: Evapotranspiration and crop coefficient of drip irrigated watermelon in Piaui Coastline, Brazil. Engenharia Agricola, 32:582-590, 2012.

BLANEY H.F., CRIDDLE W.D.: Determining consumptive use and irrigation water requirements, 1962. Available at: http://naldc.nal.usda.gov/naldc/download.xhtml?id=CAT87201264\&content=PDF (accessed March, 2016).

BOS M.G.: Irrigation efficiencies at crop production. ICID Bulletin, 29:18-25, 1980.

BOS M.G.: Summary of ICID definitions of irrigation efficiency. ICID Bulletin, 34:28-31, 1985.

BOŠNJAK Đ.: The problems of drought in the Vojvodina province and drought control measures. Field and Vegetable Crops Research, 35:391-401, 2001.

DOORENBOS J., KASSAM A.H.: Yield response to water. FAO Publication No.33, Rome, 1979.

ERDEM Y., YUKSEL A.N., ORTA A.H.: The effects of deficit irrigation on watermelon yield, water use and quality characteristics. Pakistan Journal of Biological Sciences, 4:785-789, 2001.

ERDEM Y., YUKSEL A.N.: Yield response of watermelon to irrigation shortage. Scantia Horticulturae, 98:365-383, 2003. 
ERDEM Y., ERDEM T., ORTA A.H., OKURSOY H.: Irrigation scheduling for watermelon with crop water stress index (CWSI). Journal of Central European Agriculture, 4:449-460, 2005.

FAO: Crop water information: Watermelon, 2015. Available at: http://www.fao.org/nr/water/cropinfo_watermelon.html (accessed March, 2016).

HERGREAVES G.H., SAMANI Z.A.: Reference crop evapotranspiration from temperature. Applied Engineering in Agriculture, 1:96-99, 1985.

HOWELL T.A.: Enhancing water use efficiency in irrigated agriculture. Agronomy Journal, 93:281-289, 2001.

JONES J.W., ALLEN L.H., SHIH S.F., ROGERS J.S., HAMMOND L.C., SMAJSTRALA A.G., MARTSOLF J.D. Estimated and measured evapotranspiration for Florida climate, crops and soils. Florida Agricultural Experiment Stations Bulletin, Agricultural Experiment Stations, Institute of Food and Agricultural Science, University of Florida, 1984.

KIRNAK H., DOGAN E.: Effect of seasonal water stress imposed on drip irrigated second crop watermelon grown in semi-arid climatic conditions. Irrigation Science, 27:155-164, 2009.

KOBOSSI K., KAVEH F.: Sensitivity analysis of Doorenbos and Kassam (1979) crop water production function. African Journal of Agricultural Research, 5:2399-2417, 2010.

KUSCU H., TURHAN A., OZMEN N., AYDINOL P., BUYUKCANGAZ H., DEMIR A.O.: Deficit irrigation effects on watermelon (Citrullus Vulgaris) in a sub humid environment. The Journal of Animal and Plant Sciences, 25:1652-1659, 2015.

MIRANDA F.R., OLIVEIRA J.J.G., SOUZA F.: Evapotranspiração máxima e coeficiente de cultivo para a cultura da melancia (Evapotranspiration and crop coefficients for drip-irrigated watermelon). Revista Ciência Agronômica, 35:36-43, 2004.

PEJIĆ B., GVOZDANOVIĆ-VARGA J., MILIĆ S., IGNJATOVIĆ-ĆUPINA A., KRSTIĆ DJ., ĆUPINA B.: Effect of irrigation schedules on yield and water use of onion (Allium cepa L.). African Journal of Biotechnology, 10:2644-2652, 2011.

STATISTICAL YEARBOOK OF SERBIA, 2004. Available at: http://webrzs.stat.gov.rs/WebSite/Default.aspx (accessed March, 2016).

SENYIGIT V.: The effects of different irrigation methods doses and forms on the yield and quality of watermelon. M.Sc. Disertation, Institute Agronomique Meditaerraneen de Bari, 1998.

SIMSEK M., KACIRA M., TONKAZ T.: The effects of different drip irrigation regimes on watermelon [Citrullus lanatus (Thunb.)] yield and yield components under semi-arid climatic conditions. Australian Journal of Agricultural Research, 55:11491157, 2004.

TINGWU L., JUAN X., GUANGYONG L., JIANHUA M., JIANPING W., ZHIZHONG L., JIANGUO Z.: Effect of drip irrigation with saline water on water use efficiency and quality of watermelons. Water Resources Management, 17:395-408, 2003. WANG Z., ZERIHUM D., FEYEN J.: General irrigation efficiency for field water management. Agricultural Water Management, 30:123-132, 1996.

\section{EFIKASNOST KORIŠĆENJA VODE LUBENICE NAVODNJAVANE KAPANJEM, U UMERENIM KLIMATSKIM USLOVIMA}

Izvod: Cilj istraživanja, sprovedenog u Vojvodini, bio je da se analizira efekat navodnjavanja kapanjem na prinos, evapotranspiraciju i produktivnost vode u usevu lubenice (Cirullus lanatus Thunb.), gajene na foliji. Vreme zalivanja je određeno na osnovu vodnog bilansa. Dnevne vrednosti evapotranspiracije su obračunate korišćenjem referentne evapotranspiracije i koeficijenta useva. Prinos lubenice u uslovima navodnjavanja (37,28 t/ha) bio je statistički značajno veći u odnosu na prinos u uslovima bez navodnjavanja (9,98 t/ha). Evapotranspiracija lubenice u uslovima navodnjavanja bila je $398 \mathrm{~mm}$ i $117 \mathrm{~mm}$ na nenavodnjavanoj varijanti. Obračunata vrednost koeficijenta opadanja prinosa od 1,04 za period vegetacije ukazuje da je relativno smanjenje prinosa bilo skoro jednako relativnom deficitu evapotranspiracije. Efikasnost korišćenja vode navodnjavanjem i evapotranspiracijom iznosila je $9,93 \mathrm{~kg} / \mathrm{m}^{3}$ and $10,29 \mathrm{~kg} / \mathrm{m}^{3}$, redom. Dobijeni rezultati mogu poslužiti kao dobra osnova za proizvođače lubenice u regionu, u smislu poboljšanja i optimizacije navodnjavanja.

Ključne reči: navodnjavanje, efikasnost korišćenja vode, koeficijent opadanja prinosa

Received / Primljen: 27.05.2016.

Accepted / Prihvaćen: 20.07.2016. 